\title{
Predation of Sternopygus macrurus (Bloch \& Schneider, 1801) by Micrurus surinamensis (Cuvier, 1817) in one fragment forest in Amazon, Brazil
}

\author{
F. Corrêa ${ }^{a *}$, J. S. Araújo ${ }^{b}$, L. J. S. Vieira ${ }^{a}$ and M. B. Souza ${ }^{a}$ \\ aLaboratório de Herpetologia, Universidade Federal do Acre, Rodovia BR 364, Km 04, Distrito Industrial, \\ CEP 69915-900, Rio Branco, AC, Brazil

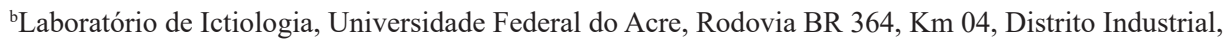 \\ CEP 69915-900, Rio Branco, AC, Brazil \\ *e-mail: correafecologia@yahoo.com.br
}

Received: April 10, 2017 - Accepted: May 18, 2017 - Distributed: November 30, 2018

(With 1 figure)

\begin{abstract}
Micrurus surinamensis (Squamata: Elapidae) is a snake with a nocturnal life habit and semi-aquatic, feeding by fish (Martins and Oliveira, 1998), it is easily recognized by having a large flat head, covered by red shields outlined by black and for being the only species of the genus with the fourth supralabial in contact with the eye (Roze, 1996). Its distribution includes equatorial forests of South America, in Brazil the species occurs in the States of Acre, Amapá, Amazonas, Goiás, Roraima, Rondônia, Pará, Maranhão, Tocantins, and Mato Grosso (Hoge and Lancini, 1962; Campbell and Lamar, 2004; Passos and Fernandes, 2005; Silva Junior et al., 2008). Studies that seek to describe preys not yet registered in the serpents' diet is of great importance for understanding the trophic relations of the ecosystem and its implications for conservation. In this context, paper involving diet and behavior of Micrurus species are scarce due to Cryptozoic and fossorial habits. For the Acre state, Silva et al. (2010) reported the wealth and diet of snakes in the state, in this study was reported the diet of five species of Micrurus, but not the great diversity of fish in their diet. Studies dealing with the feeding ecology or just new prey records are of great importance, because they show potencies available food resources to be used, as well as the energy flow among the different taxonomic groups, on this case trophic interaction among snakes and fishes. Sousa et al. (2014) describe that obtaining more detailed elements, from the studies feeding ecology how, ongenetic variation, bioenergy, predator-prey relationship or records of new prey is a key step to better understand the trophic ecology of snakes in temperate regions. Thereat, this paper aims to record for the first time the predation of Sternopygus macrurus (Gymnotiformes: Sternopygidae) by the snake Micrurus surinamensis in a natural reserve of Amazonia, Brazil.

One specimen of $M$. surinamensis was collected on January $24^{\text {th }}, 2004$, manually in a two order stream in an Amazon forest fragment, Humaitá Forest Reserve, the city of Porto Acre (9॰45'19'S/6740'18'W), located approximately $30 \mathrm{Km}$ from the Rio Branco city, Acre
\end{abstract}

state. The reserve has an area of over 2,000 hectares, covered by Forest Open Tropical having palm trees and/or bamboo, and on a smaller scale dense Tropical Forest and Floodplain Forest on the banks of the Acre River (Acre, 2006). The average annual rainfall is $1940 \mathrm{~mm}$, occurring periods with more intense precipitations between the months of January and March and lower pronounced precipitation between the months of July and August. The annual average temperature is $26^{\circ} \mathrm{C}$, with sudden drops of temperature, with minimum temperatures below $10{ }^{\circ} \mathrm{C}$ that occur during the dry period due to the polar fronts advance (Duarte, 2006). The collected individual was fixed in $10 \%$ formalin, transferred to $70 \%$ alcohol after $24 \mathrm{hr}$ and its identification was based according to (Roze, 1996), then total length (TL, cm) was obtained. The digestive tract was extracted for the stomach analysis and the prey was identified according to (Cella and Crampton, 2013), next the prey total length (TL, cm) was obtained. The collected individual was deposited in the herpetological collection of the Federal University of Acre (UFAC / 066).

The serpent, M. surinamensis, presented a TL of $84.4 \mathrm{~cm}$ (Figure 1A) and the fish item Sternopygus macrurus (Bloch $\&$ Schneider, 1801) with TL of $45.9 \mathrm{~cm}$ (Figure 1B) was recorded in the stomach contents. This was ingested in the anteroposterior direction, indicating a predation tactic by ambush. Sternopygidae is composed of six genera and 36 species, and is distributed in Transandine drainage, found in hydrographic basins of the Amazon and Orinoco (Cella and Crampton, 2013). Sternopygus macrurus is identified as having an anguilliform body shape does not have a layer of skin on the eyes and its pigmentation is uniformly dark, presenting a prominent spot on the dorsum-posterior portion of the operculum (Cella and Crampton, 2013). It can be found in different habitats with the presence of aquatic macrophytes, such as the banks of small streams and seasonally flooded areas. Their feeding is based mainly on the consumption of insect larvae and small crustaceans (Villa-Navarro and Losada-Prado, 2004). 


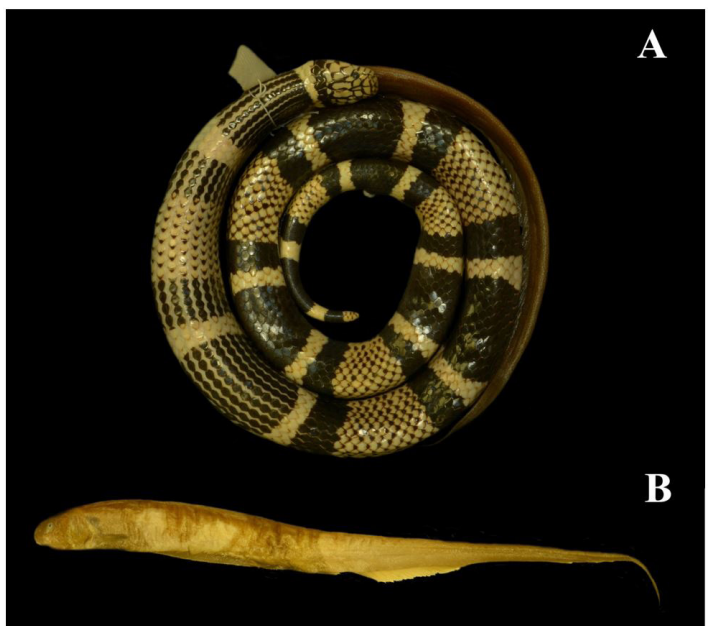

Figure 1. Micrurus surinamensis above (A) and the prey Sternopygus macrurus below (B), collected in one stream in the reserve Humaitá, Amazon, Brazil.

Usually, Micrurus species are very specialized predators, with a preference for food items with elongated bodies (Martins and Oliveira, 1998; Campbell and Lamar, 2004). In addition, several species of vertebrates, consumed by Micrurus species, which occupied a similar niche as the predator itself (Martins and Oliveira, 1998). In this case, M. surinamensis inhabits aquatic sites, which leads to predation of fish or other animals that have the same habit. In predation of fish by serpents, the author Roze (1996) registered different taxonomic species groups as Callichthys callichthys (Siluriformes), Gymnotus carapo (Gymnotiformes), and Synbranchus marmoratus (Synbranchiformes). In general, studies that seek to record the predation of fish by serpents are important since they can show possible prey species occurring in the place, where snakes serve with good samplers. For the state of Acre, a paper with this subject is still scarce, so this is the first step for future studies on the trophic ecology of the species of Amazon southwest.

\section{References}

ACRE. Governo do Estado, 2006. Programa Estadual de Zoneamento Ecológico Econômico do Estado do Acre Fase II. Escala 1:250.000. Rio Branco: SEMA. 356 p.

CAMPBELL, J.A. and LAMAR, W.W. 2004. The venomous reptiles of the western hemisphere. New York: Comstock. 810 p.

CELLA, R.A. and CRAMPTON, W.G.R., 2013. Sternopygidae. In: L.J. QUEIROZ, G. TORRENTE-VILARA, W.M. OHARA, T.H.S. PIRES, J. ZUANON, C.R.C. DORIA, eds. Peixes do Rio Madeira. 1st ed. São Paulo: Dialeto, vol. 3, pp. 218-229.

DUARTE, A.F., 2006. Aspectos da climatologia do Acre, Brasil, com base no intervalo 1971-2000. Revista Brasileira de Meteorologia, vol. 21 , no. 3, pp. 308-317.

HOGE, A.R. and LANCINI, A.R., 1962. Sinopsis de las serpientes venenosas de Venezuela. Publicaciones Ocasionales del Museo de Ciencias Naturales, vol. 1, pp. 1-24.

MARTINS, M. and OLIVEIRA, M.E., 1998. Natural history of snakes in forests of the Manaus region, Central Amazonia, Brazil. Herpetological Natural History, vol. 6, pp. 78-150.

PASSOS, P. and FERNANDES, D.S., 2005. Variation and taxonomic status of the coral snake Micrurus surinamensis (Cuvier, 1817) (Serpentes: Elapidae). Zootaxa, vol. 953, no. 953, pp. 1-14. http://dx.doi.org/10.11646/zootaxa.953.1.1.

ROZE, J.A., 1996. Coral snakes of the Americas: biology, identification, and venoms. Malabar: Krieger Publishing Company. 328 p.

SILVA JUNIOR, N.J., SILVA, H.L.R. and PESSOA, A.M., 2008. Micrurus surinamensis (Surinam Coral snake): geographic distribution. Herpetological Review, vol. 39, pp. 372.

SILVA, M.V., SOUZA, M.B. and BERNARDE, P.S., 2010. Riqueza e dieta de serpentes do Estado do Acre, Brasil. Revista Brasileira de Zoociências, vol. 12, pp. 165-176. http://dx.doi.org/10.1590/ S1516-35982010000100022.

SOUSA, K.R.M., PRUDENTE, A.L.C. and MASCHIO, F.M., 2014. Reproduction and diet of Imantodes cenchoa (Dipsadidae: Dipsadinae) from the Brazilian Amazon. Zoologia, vol. 31, no. 1, pp. 8-19. http://dx.doi.org/10.1590/S1984-46702014000100002.

VILLA-NAVARRO, F.A. and LOSADA-PRADO, S., 2004. Aspectos bioecologicos del caloche, Sternopygus macrurus (Gymnotiformes: Sternopygidae), en (a represa de prado, tollma, Colombia). Dahlia: Revista de La Asociación Colombiana de Ictiólogos, vol. 7, pp. 49-56. 